See discussions, stats, and author profiles for this publication at: https://www.researchgate.net/publication/226487323

\title{
Early stages of biofilm succession in a lentic freshwater environment
}

Article in Hydrobiologia · January 2004

DOI: 10.1023/B:HYDR.0000020314.69538.2C

\section{CITATIONS}

58

5 authors, including:

Sekar Raju

Xi'an Jiaotong-Liverpool University

118 PUBLICATIONS 1,921 CITATIONS

SEE PROFILE

Nandakumar Kanavillil

Lakehead University Orillia Campus

62 PUBLICATIONS 1,052 CITATIONS

SEE PROFILE

Some of the authors of this publication are also working on these related projects:

Biomineralisation Engineering Applications View project

Project Thermal Ecology View project
SEE PROFILE 


\title{
Early stages of biofilm succession in a lentic freshwater environment
}

\author{
R. Sekar ${ }^{1,2, *}$, V. P. Venugopalan, K. Nandakumar, K. V. K. Nair \& V. N. R. Rao ${ }^{1}$ \\ Water and Steam Chemistry Laboratory, Bhabha Atomic Research Centre Facilities, Kalpakkam 603 102, \\ Tamil Nadu, India \\ ${ }^{1}$ Centre of Advanced Study in Botany, University of Madras, Guindy Campus, Chennai 600 025, India \\ ${ }^{2}$ Present address: Dept of Molecular Ecology, Max-Planck Institute for Marine Microbiology, \\ Celsiusstrasse 1, 28359 Bremen, Germany \\ *Author for correspondence; Tel: 0049-421-2028-545. Fax: 0049-421-2028-580. E-mail: sraju@mpi-bremen.de
}

Key words: colonization, succession, microalgae, biofilms, green algae, diatoms, cyanobacteria

\begin{abstract}
Initial events of biofilms development and succession were studied in a freshwater environment at Kalpakkam, East Coast of India. Biofilms were developed by suspending Perspex (Plexiglass) panels for 15 days at bimonthly intervals from January 1996 to January 1997. Changes in biofilm thickness, biomass, algal density, chlorophyll $a$ concentration and species composition were monitored. The biofilm thickness, biomass, algal density and chlorophyll $a$ concentration increased with biofilms age and colonization was greater during summer (March, May and July) than other months. The initial colonization was mainly composed of Chlorella vulgaris, Chlorococcum humicolo (green algae), Achnanthes minutissima, Cocconeis scutellum, C. placentula (diatoms) and Chroococcus minutus (cyanobacteria) followed by colonial green algae such as Pediastrum tetras, P. boryanum and Coleochaete scutata, cyanobacteria (Gloeocapsa nigrescens), low profile diatoms (Amphora coffeaeformis, Nitzschia amphibia, and Gomphonema parvulum) and long stalked diatoms (Gomphoneis olivaceum and Gomphonema lanceolatum). After the 10th day, the community consisted of filamentous green algae (Klebshormidium subtile, Oedogonium sp., Stigeoclonium tenue and Ulothrix zonata) and cyanobacteria (Calothrix elenkinii, Oscillatoria tenuis and Phormidium tenue). Based on the percentage composition of different groups in the biofilm, three phases of succession could be identified: the first phase was dominated by green algae, the second by diatoms and the third phase by cyanobacteria. Seasonal variation in species composition was observed but the sequence of colonization was similar throughout the study period.
\end{abstract}

\section{Introduction}

Microbial colonization on hard surfaces is a common phenomenon in natural aquatic environments which has both ecological and industrial significance (Ford et al., 1989). Submerged surfaces, including surfaces coated with toxic paints, are readily colonized by bacteria and microalgae (Callow, 1986; Cooksey \& Cooksey, 1995), which cause problems to ship surfaces, cooling systems and other marine-based industries (Pederson, 1990; Hudson \& Burke, 1994; Udayakumar et al., 1998). The formation of a primary biofilm over surfaces favours subsequent colonization by other organisms and facilitates corrosion. Microal- gae are among the major components in the freshwater biofilms (Callow, 1993).

Microalgal colonization has been studied in different aquatic environments using various natural and artificial substrata (Brown, 1976; Hoagland et al., 1982; Oemke \& Burton, 1986; Acs \& Kiss, 1993; Lowe et al., 1996). A three dimensional microalgal succession was observed in biofilms by earlier workers and it was reported that microalgal succession is analagous to higher plant succession in terrestial environments (Hudon \& Bourget, 1981; Hoagland et al., 1982; Korte \& Blinn, 1983; Roemer et al.,1984). Among the diatoms, succession process has been found to be influenced by water velocity, size, immigration and 
reproduction rate of the organisms (Oemke \& Burton, 1986; Steinman \& McIntire, 1986; Stevenson \& Peterson, 1989; Acs \& Kiss, 1993; Johnson et al., 1997).

Most of the earlier studies on microalgal colonization on artificial substrata in freshwater environments have been focused on diatoms. Studies representing the complete microalgal assemblages are limited. Moreover, the previous succession studies have been carried out in lotic systems where water movement is likely to influence colonization. In the present work, we have studied the early events of colonization and succession of the biofilm in an undisturbed lentic freshwater system, taking into account all the biofilm components such as green algae, diatoms and cyanobacteria, to find out critical changes in microalgal colonization and succession, which take place during the early development of biofilm.

\section{Materials and methods}

\section{Site description}

This study was conducted in an open freshwater reservoir located at Kalpakkam $\left(22^{\circ} 33^{\prime} \mathrm{N}, 80^{\circ} 11^{\prime} \mathrm{E}\right)$, $60 \mathrm{~km}$ south of Madras, on the East Coast of India. The reservoir serves as the source of cooling water for a power reactor located in the same campus, and is 1.7 hectares in area, with a maximum depth of $2.3 \mathrm{~m}$ at the overflow level. The reservoir receives water from a sub soil river bed. The physico-chemical and characteristics of the reservoir water during the study period was analyzed as per standard methods (APHA, 1989).

\section{Panel preparation and immersion}

The colonization and succession of the biofilm were studied at bimonthly intervals for the period of one year from January 1996 to January 1997 by suspending clean Perspex (Plexiglass) test panels of two sizes, namely small $(7 \times 3 \times 0.3 \mathrm{~cm})$ for microscopic observation and large $(15 \times 10 \times 0.3 \mathrm{~cm})$ for biomass and chlorophyll measurements. The panels were fastened on to a stainless steel frame and suspended vertically $0.5 \mathrm{~m}$ from the water surface.

\section{Panel analysis}

Duplicate panels of both sizes were retrieved periodically (i.e. after 1, 2, 3, 4, 5, 7, 10 and 15 days of exposure). The panels were rinsed with filtered reservoir water to remove loosely attached planktonic forms. The small panels were used for the measurement of biofilm thickness and for studying qualitative and quantitative distribution of biofilm species. After wiping one side (randomly chosen) of the small panels, the biofilm on the other side was observed directly under a Nikon Ophitiphot microscope. Biofilm thickness was measured by the method of Bakke \& Olsson (1986). In this method, the distance travelled by the microscope stage (read off the stage micrometer) is measured while changing the focus from the base (biofilm substratum interface) to top of the biofilm. Thickness measurements were taken from 10 random fields and averaged to get mean wet film thickness. Algal density analyses were made at $200 \times$ or $400 \times$ magnification; a higher magnification was used for species identification, when required. The algal density and species composition were analyzed following the method of Brown (1976). As per this method, single cells, colonies and filamentous forms (as the case may be) were scored as individuals (Sekar et al., 1998). The algal species were identified using standard manuals (Hustedt, 1930; Desikachary, 1959; Philipose, 1967; Prescott, 1978). The total algal density was expressed as organisms $\mathrm{cm}^{-2}$.

The biofilm on the larger panels was scraped with a soft, sterile nylon brush and made up to a known volume using distilled water. The samples were filtered through preweighed $0.45 \mu \mathrm{m}$ Whatman GF/C filters and the filters were kept in Furnace at $450^{\circ} \mathrm{C}$ for a minimum $6 \mathrm{~h}$ and again they were weighed and the biomass was expressed as ash free dry weight (APHA, 1989). Aliquot samples were also filtered through $0.45 \mu \mathrm{m}$ Millipore filters and the chlorophyll was cold extracted with $90 \%$ acetone for $4-6 \mathrm{~h}$ in dark. After the complete extraction, the absorbance of clear supernatant was read at 750, 665, 664 and $630 \mathrm{~nm}$ using Spectrophotometer (Jeffrey \& Humphrey, 1975).

\section{Data analysis}

The variation in biofilm thickness, algal density, biomass and chlorophyll $a$ with respect to exposure time in days and between months were compared using one way and two way ANOVA (Sokal \& Rohlf, 1987) after the data were log transformed. The correlation between algal density and biofilm thickness, biomass and chlorophyll $a$ was calculated using Pearsons correlation test. Species diversity was calculated using the Shannon-Wiener index $\left(\mathrm{H}^{\prime}\right)$ (Odum, 1971) and dominance index (D) (Margalef, 1958). Evenness of 
Table 1 . Water quality parameters (range) as measured during the study period (January 1996-January 1997)

\begin{tabular}{lc}
\hline Parameters & Range \\
\hline Water temperature ${ }^{\circ} \mathrm{C}$ & $31.0-33.1$ \\
$\mathrm{pH}$ & $8.0-8.9$ \\
Conductivity $\left(\mu \mathrm{S} \mathrm{cm}^{-1}\right)$ & $249-440$ \\
Total suspended solids $\left(\mathrm{mg} \mathrm{l}^{-1}\right)$ & $15-20$ \\
Secchi disc transparency $(\mathrm{m})$ & $2.2-2.3$ \\
Water movement* & Negligible \\
Dissolved Oxygen $\left(\mathrm{mg}^{-1}\right)$ & $7.2-9.2$ \\
Total alkalinity $\left(\mathrm{mg} \mathrm{CaCO}_{3} 1^{-1}\right)$ & $70-128$ \\
Total hardness $\left(\mathrm{mg} \mathrm{CaCO}_{3} \mathrm{l}^{-1}\right)$ & $58-104$ \\
Chloride $\left(\mathrm{mg}^{-1}\right)$ & $26-58$ \\
Nitrate-N $\left(\mu \mathrm{g} \mathrm{l}^{-1}\right)$ & $15-325$ \\
Nitrite-N $\left(\mu \mathrm{g}^{-1}\right)$ & $1.5-8.8$ \\
Phosphate-P $\left(\mu \mathrm{g} \mathrm{l}^{-1}\right)$ & $4-44$ \\
Silicate-Si $\left(\mathrm{mg} \mathrm{l}^{-1}\right)$ & $1.5-4.2$ \\
Chlorophyll $a\left(\mu \mathrm{g} \mathrm{l}^{-1}\right)$ & $9.1-32.6$ \\
\hline
\end{tabular}

species distribution was calculated using the evenness index of Pielou (1966).

\section{Results}

\section{Biofilm characteristics}

The data on limnological parameters during January 1996-January 1997 are given in Table 1 . The changes in biofilm thickness, density, biomass and chlorophyll $a$ in biofilms during the same period are given in Figure $1(\mathrm{a}-\mathrm{d})$. Biofilm thickness varied significantly with exposure time (one way ANOVA, $F_{25.63}=14 ; p<$ $0.001)$, however the variation between months or the interaction between exposure time and months (two way ANOVA, $F_{0.83}=28 ; p>0.05$ ) were not significant. Thickness of the biofilm achieved a maximum during May 1996 and was minimum during January 1996. Biofilm thickness was significantly correlated with algal density $\left(r^{2}=0.582 ; p<0.05\right)$.

Algal density showed significant variations with exposure time (one way ANOVA, $F_{24.71}=14 ; p<$ 0.001 ) and between months (one way ANOVA, $\left.\mathrm{F}_{75.22}=2 ; p<0.001\right)$. The interaction between exposure time and months was also significant (two way ANOVA, $F_{2.84}=28 ; p<0.001$ ). Density was highest during May 1996, followed by March and July 1996 and was lowest during September, November and January 1996 and 1997. The algal density was correlated significantly with biomass $\left(r^{2}=0.546\right.$; $p<0.05)$ and chlorophyll $a\left(r^{2}=0.768 ; p<0.001\right)$.

The biofilm biomass varied significantly with biofilm age (one way ANOVA, $F_{44.84}=14 ; p<$ 0.001 ) and between months (one way ANOVA, $F_{50.39}$ $=2 ; p<0.001)$, but the interaction between exposure time and months was not significant (two way ANOVA, $\left.F_{1.54}=28 ; p>0.05\right)$. The biomass was maximal during May 1996 followed by March and July 1996 and was minimal during September and November 1996. The biomass was significantly correlated with algal density $\left(r^{2}=0.55 ; p<0.05\right)$ and chlorophyll $a\left(r^{2}=0.934 ; p<0.001\right)$.

Chlorophyll $a$ also showed similar results as biomass and algal density. The maximum concentration of chlorophyll was observed during May 1996 and concentration varied significantly with exposure time (one way ANOVA, $F_{55.9}=14 ; p<0.001$ ) and months (one way ANOVA, $F_{64.6}=2 ; p<0.001$ ). The interaction between exposure time and months was also significant (two way ANOVA, $F_{2.68}=28 ; p<0.05$ ).

\section{Species composition and sequence of colonization/succession}

The species observed in the biofilms are given in Table 2. A total of 108 species could be identified in the biofilms, comprising 20 genera and 38 species of Chlorophyceae, 22 genera and 41 species of Bacillariophyceae, 17 genera and 26 species of Cyanobacteria, 2 genera of Chrysophyceae and 1 genus of Dinophyceae. Chlorophyceae, Bacillariophyceae and Cyanobacteria were the dominant groups of organisms found on the substratum.

Ankistrodesmus convolutus, A. falcatus, Chlorococcum humicolo, Chlorella vulgaris, Closterium sp., Cosmarium spp., Scenedesmus spp. and Staurastrum enorme were the major green algal species observed during the initial phase, among which Chlorella vulgaris, Chlorococcum humicolo were relatively more abundant. Coleochaete spp., Klebshormidium subtile, Oedogonium sp., Pediastrum boryanum, Stigeoclonium tenue and Ulothrix zonata were observed during later phase.

Diatoms such as Achnanthes minutissima, Cocconeis spp., Coscinodiscus sp., Gomphoneis olivaceum, Navicula spp., Nitzschia spp. were observed during the early stages in the biofilms. Among them, Achnanthes minutissima and Cocconeis scutellum were more abundant. During the later phase, 
Table 2. Algal species recorded in the biofilm during the study period

\begin{tabular}{|c|c|c|c|c|c|c|c|c|}
\hline \multirow[t]{2}{*}{ Algal species } & \multicolumn{8}{|c|}{ Days of panel immersion } \\
\hline & 1 & 2 & 3 & 4 & 5 & 7 & 10 & 15 \\
\hline \multicolumn{9}{|l|}{ Chlorophyceae } \\
\hline Ankistrodesmus convolutus Corda & + & + & + & - & - & - & - & - \\
\hline A. falcatus (Corda) Ralfs. & - & - & + & + & - & - & - & - \\
\hline Asterococcus limneticus G.M. Smith & - & - & - & + & - & - & - & - \\
\hline Bulbochaete insignis Pringsh & - & - & - & - & + & - & - & - \\
\hline Chlorella vulgaris Beijerinck & ++ & +++ & +++ & + & + & - & - & - \\
\hline Chlorococcum humicolo (Näg.) Rebenh. & + & ++ & +++ & +++ & ++ & + & - & - \\
\hline $\begin{array}{l}\text { Chlorosarcina consociata (Klebs) } \\
\text { G.M. Smith }\end{array}$ & - & - & - & - & + & - & - & - \\
\hline Chlamydomonas sp. & - & + & - & - & - & - & - & - \\
\hline Closterium sp. & - & + & + & - & - & + & - & - \\
\hline Coelastrum microporum Näg & + & + & - & + & + & - & - & - \\
\hline Coleochaete orbicularis Pringh & - & - & - & - & - & - & + & + \\
\hline C. pulvinata A. Br. & - & - & - & - & - & - & + & + \\
\hline C. scutata de Bréb. & - & - & - & - & - & + & + & + \\
\hline Cosmarium granatum Bréb. & - & - & + & + & - & - & - & - \\
\hline C. impressulum Elfv. & + & + & - & + & + & - & - & - \\
\hline C. pyramidatum Bréb. in Ralfs. & - & + & + & - & - & - & - & - \\
\hline C. reginelli Wille & - & - & + & + & - & - & - & - \\
\hline C. subquadratum Nordst. & + & + & + & + & - & - & - & - \\
\hline C. subtumidium Nordst. & - & + & + & + & - & - & - & - \\
\hline Crucigena quadrata Morren & - & - & - & + & + & + & - & - \\
\hline C. tetrapedia (Kirchn.) W. et. G.S. West & - & - & - & + & - & - & - & - \\
\hline $\begin{array}{l}\text { Klebshormidium subtile (Kirchner) } \\
\text { Chodat }\end{array}$ & - & - & - & - & - & - & + & + \\
\hline Oedogonium sp. & - & - & - & - & - & - & + & + \\
\hline $\begin{array}{l}\text { Pediastrum boryanum (Turp.) } \\
\text { Meneghini }\end{array}$ & - & - & - & - & + & + & + & + \\
\hline P. duplex Meyen & - & - & + & + & + & + & - & - \\
\hline P. simplex Meyen & - & - & + & + & + & - & - & - \\
\hline P. tetras (Ehr.) Ralfs. & - & - & + & + & + & + & - & - \\
\hline $\begin{array}{l}\text { Scenedesmus abundans (Kirchner) } \\
\text { Chodat }\end{array}$ & + & - & + & + & - & - & - & - \\
\hline S. acuminatus (Lagerh.) Chodat & - & + & - & - & - & - & - & - \\
\hline S. bijugatus (Turpin) Kütz. & - & - & + & + & + & - & - & - \\
\hline S. perforatus Lemm. & - & - & + & - & - & - & - & - \\
\hline S. quadricauda (Turp.) Bréb. & - & - & + & + & + & - & - & - \\
\hline S. quadricauda v. quadrispina Chodat & + & + & + & - & - & - & - & - \\
\hline Selenastrum gracile Reinsch & - & - & + & + & + & - & - & - \\
\hline Spirogyra sp. & - & - & - & - & - & + & + & + \\
\hline Staurastrum enorme Ralfs. & + & + & - & - & - & - & - & - \\
\hline Stigeoclonium tепие Rabenh. & - & - & - & - & - & + & + & + \\
\hline $\begin{array}{l}\text { Ulothrix zonata (Weber et Mohr) Kütz. } \\
\text { Bacillariophyceae }\end{array}$ & - & - & - & - & - & + & + & + \\
\hline Achnanthes microcephala Kütz. & + & + & + & - & - & - & - & - \\
\hline A. minutissima Kütz. & ++ & ++ & ++ & + & + & - & - & - \\
\hline Amphora coffeaformis (Agardh) Kütz. & + & + & + & + & ++ & + & + & + \\
\hline A. ovalis Kütz. & - & - & + & + & + & + & + & + \\
\hline Amphipleura pellucida Kütz. & - & - & + & - & - & - & - & - \\
\hline
\end{tabular}


Table 2. Continued

\begin{tabular}{|c|c|c|c|c|c|c|c|c|}
\hline \multirow[t]{2}{*}{ Algal species } & \multicolumn{8}{|c|}{ Days of panel immersion } \\
\hline & 1 & 2 & 3 & 4 & 5 & 7 & 10 & 15 \\
\hline Cocconeis disculus Schum & + & + & + & ++ & + & + & - & - \\
\hline C. placentula (Ehr) Cleve & + & + & + & + & ++ & + & - & - \\
\hline C. scutellum Ehr.v. parva Grun. & + & + & ++ & ++ & + & - & - & - \\
\hline Coscinodiscus sp. & + & + & - & - & - & - & - & - \\
\hline Cyclotella menginiana Kütz. & - & - & + & - & - & - & - & - \\
\hline Cymbella affinis Kütz. & - & + & + & + & + & + & ++ & + \\
\hline C. minuta Hilse & - & - & - & - & + & + & + & + \\
\hline C. tumida (Breb) v. Heurck & - & + & + & + & + & ++ & ++ & - \\
\hline Diatoma vulgare Bory & - & - & - & - & - & + & - & - \\
\hline Diploneis ovalis (Hilse) Cleve & - & - & - & + & + & - & - & - \\
\hline Eunotia sp. & - & - & + & + & + & - & - & - \\
\hline Fraglaria construens (Ehr.) Grun. & - & + & + & + & + & + & + & + \\
\hline F. vaucheriae (Kütz) Peter & - & - & - & + & + & + & - & - \\
\hline Gomphoneis olivaceum (Lyngb.) Kütz. & - & + & + & + & ++ & ++ & +++ & ++ \\
\hline Gomphonema lanceolatum Ehr. & - & - & + & + & + & ++ & ++ & + \\
\hline G. parvulum Kütz. & - & - & - & + & + & + & + & + \\
\hline Gyrosigma acuminatum (Kutz.) Rabh. & - & + & + & - & - & - & - & - \\
\hline Lichmophora sp. & - & - & + & + & + & + & - & - \\
\hline Melosira amphigua (Grun.) O.Muller & - & - & + & + & + & - & - & - \\
\hline M. granulata (Ehr.) Ralfs. & - & - & - & + & + & - & - & - \\
\hline Meridion circulare (Grev.) Ag. & - & - & - & - & - & - & + & - \\
\hline Navicula cryptocephala Kutz. & + & + & + & + & + & - & - & - \\
\hline N. elegans Wm. Sm. & - & - & + & + & - & - & - & - \\
\hline N. krasskei Hust. & + & + & + & + & + & + & + & - \\
\hline N. pelliculosa (Breb) Hilse & - & - & - & - & + & - & - & - \\
\hline Nitzschia amphibia Grun. & + & + & + & + & + & ++ & ++ & ++ \\
\hline N. dissipata (Kütz.) Grun. & - & - & - & - & + & - & - & - \\
\hline N. frustulum Kütz. & + & + & - & + & - & - & - & - \\
\hline N. microcephala Grun. & - & - & - & - & + & - & - & - \\
\hline N. ovalis Arnott & + & - & - & - & - & - & - & - \\
\hline N. palea (Kütz.) Wm. Sm. & + & + & + & + & + & + & + & - \\
\hline Opephora martyi Heribaud & - & - & - & - & - & - & + & - \\
\hline Pinnularia subcapitata Gregory & - & - & - & - & + & + & - & - \\
\hline P. subleniaris Grun. & - & - & - & - & + & - & - & - \\
\hline Synedra radians Kütz. & - & - & - & - & - & + & + & + \\
\hline S. ulna (Nitzsch) Ehr. & - & - & - & - & - & - & + & + \\
\hline \multicolumn{9}{|l|}{ Cyanobacteria } \\
\hline Anabaena circinalis Forti & - & - & - & - & - & - & - & + \\
\hline Aphanocapsa elachista W. et. G.S. West & - & - & + & + & + & - & - & - \\
\hline Aphanothece Näg. & - & - & - & - & - & - & + & - \\
\hline Arthrospira Stizenb. & - & - & - & - & - & - & + & + \\
\hline Aulosira Kirchner & - & - & - & - & - & + & - & - \\
\hline Calothrix brevissima West, G.S. & + & + & - & + & + & + & + & + \\
\hline C. elenkinii Koss. & - & - & - & + & ++ & + & + & ++ \\
\hline Chroococcus minutus (Kütz.) Näg. & ++ & + & + & + & + & - & - & - \\
\hline C. turgidus (Kütz.) Näg. & + & + & + & - & - & - & - & - \\
\hline Cylinderospermum Kütz. & - & - & - & - & - & + & - & - \\
\hline Gloeocapsa nigrescens Näg. & - & - & - & + & + & ++ & + & + \\
\hline Lyngbya birgei Smith & - & - & - & - & - & - & + & + \\
\hline Merismophedia glauca (Ehrenb.) Näg. & + & + & + & + & + & - & - & - \\
\hline
\end{tabular}


Table 2. Continued

\begin{tabular}{|c|c|c|c|c|c|c|c|c|}
\hline \multirow[t]{2}{*}{ Algal species } & \multicolumn{8}{|c|}{ Days of panel immersion } \\
\hline & 1 & 2 & 3 & 4 & 5 & 7 & 10 & 15 \\
\hline M. punctata Meyen & - & + & + & - & - & - & - & - \\
\hline Nodularia spumigena Mertens & - & - & + & + & + & + & + & - \\
\hline Nostoc commune Vaucher & + & - & - & - & - & - & - & - \\
\hline N. muscorum Ag. & - & - & - & + & - & - & - & - \\
\hline Oscillatoria annae Van Goor & - & - & - & - & - & - & + & + \\
\hline O. princeps Vaucher ex Gomont & - & - & - & - & - & + & - & - \\
\hline O. sancta (Kütz.) Gom. & - & - & - & - & - & - & + & - \\
\hline O. tenuis Ag. & - & - & - & + & + & + & ++ & +++ \\
\hline Phormidium ambiguum Gom. & - & - & - & - & - & - & - & + \\
\hline P. foveolarum Gom. & - & - & - & - & - & - & + & + \\
\hline P. tenue (Menegh.) Gom. & - & - & - & - & - & + & ++ & ++ \\
\hline Rivularia dura (Roth) ex. Born. et. Flah. & - & - & - & - & - & + & + & + \\
\hline Scytomena hofmanii Ag. & - & - & - & - & - & - & - & + \\
\hline \multicolumn{9}{|l|}{ Chrysophyceae (Chrysophyta) } \\
\hline Dinobryon sp. & - & - & + & - & + & - & - & - \\
\hline Rhyzochrysis sp. & - & + & - & - & - & - & - & - \\
\hline \multicolumn{9}{|l|}{ Dinophyceae (Phyrrophyta) } \\
\hline Peridinium sp. & - & - & + & - & - & - & - & - \\
\hline
\end{tabular}

$+=$ Present $+++=$ Frequent $++++=$ Abundant. $-=$ Absent.
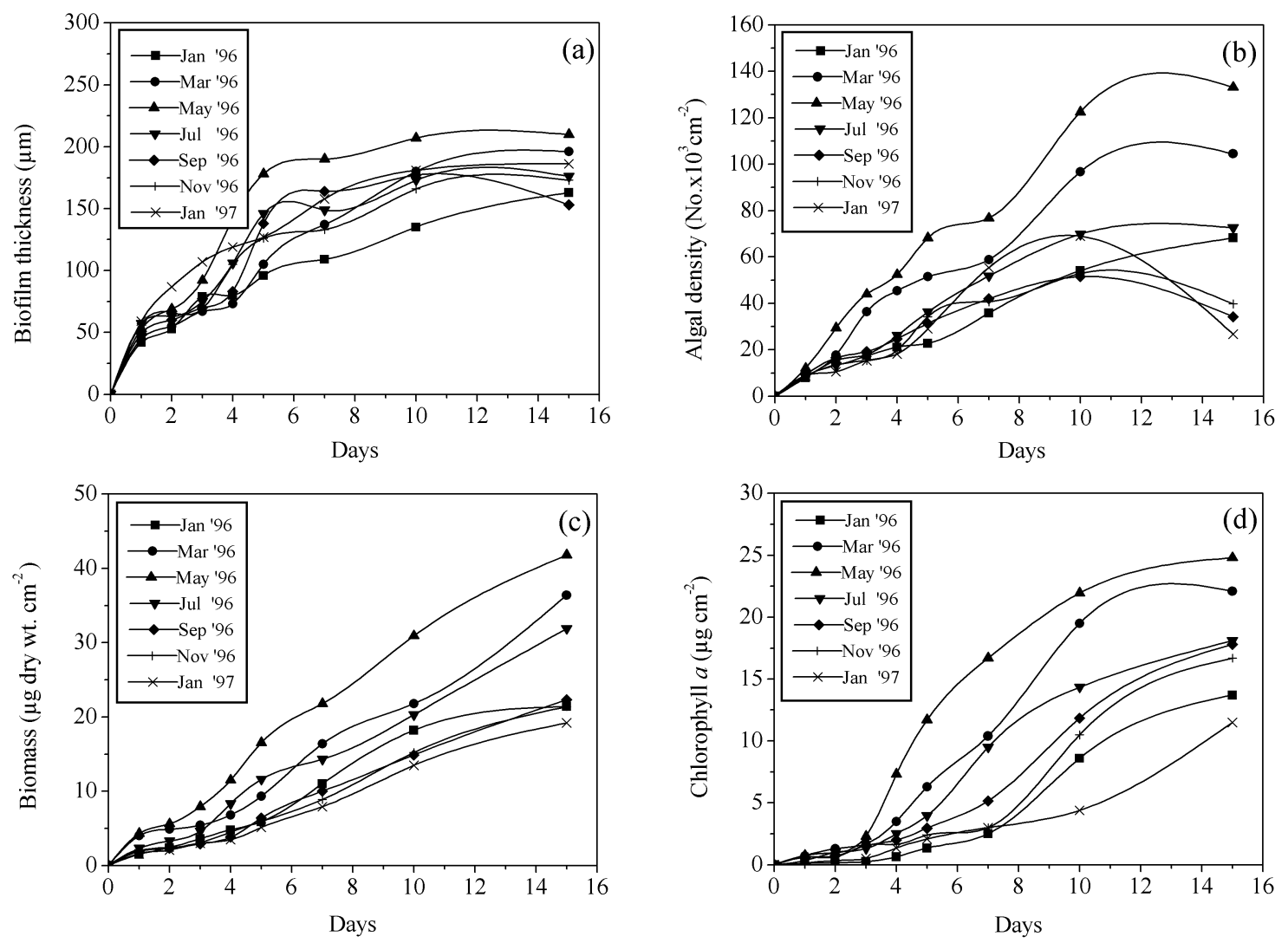

Figure 1. Changes in biofilm thickness (a), algal density (b), biomass (c) and Chlorophyll $a$ (d) during the period of study. 
diatoms such as Gomphoneis olivaceum, Gomphonema sp. and Nitzschia amphibia were observed more in the biofilm.

Cyanobacteria such as Aphanocapsa elachista, Chroococcus minutus, C. turgidus, Merismophedia glauca, $M$. punctata were observed during the early phase, among which $C$. minutus was dominant. Species such as Calothix, Lyngbya, Oscillatoria, Phormidium, Rivularia and Scytonema were observed during the later stage and among these, Oscillatoria tenuis and Phormidium tenue were relatively more abundant.

In general, the biofilm was initially dominated by Chlorella vulgaris with co-dominance of Cocconeis scutellum and Chroococcus minutus. This was followed by the emergence of Gomphoneis olivaceum along with Nitzschia amphibia (diatom), colonial forms such as Pediastrum boryanum, Coleochaete scutata (green algae) and Gloeocapsa nigrescens (Cyanobacteria). The later stages were dominated by Oscillatoria tenuis and Phormidium tenue, with Nitzschia amphibia and Gomphoneis olivaceum forming important constituents (Fig. 2).

Based on these results, the biofilms species succession could be divided into three distinct phases. The first phase (1-4 days) was dominated by green algae, the second phase (5-7 days) by diatoms and the third phase (10-15 days) by cyanobacteria. The percentage composition of each groups varied slightly with respect to months but the general trend in the sequence of colonization and succession pattern was comparable throughout the year (Fig. 3).

\section{Species diversity}

The Shannon-Wiener index showed much variation with exposure time and between months (Fig. 4). Relatively higher diversity of organisms in the biofilm during the early phases of colonization was evident from the higher Shannon-Wiener values that prevailed during 1-7 days. Evenness index values did not show much variation with respect to exposure time throughout the study period, indicating relatively even distribution of species (Fig. 4).

\section{Discussion}

Biofilm thickness, biomass build-up and microbial density on surfaces are described as functions of biofilm age (Christensen \& Characklis, 1990). Biofilm thickness is an important parameter since it deter- mines the fluid frictional resistance and heat transfer efficiency when fouling occurs in pipes and heat exchangers (Christensen \& Characklis, 1990). In the present study, parameters such as biofilm thickness, algal density, biomass and chlorophyll $a$ concentrations increased with biofilm age (=exposure time). This is in agreement with reports by Rao et al. (1997) and Sekar et al. (1998). Thickness seems to be influenced by the species composition and season as reported by Christensen \& Characklis (1990). Biofilms thickness, biomass, algal density and chlorophyll $a$ showed variation with respect to different months and the algal density showed significant correlation with all other parameters.

The numerical density in the biofilm varied with age and between months. In general, the number increased up to 5-7 days after which it decreased. The biofilm was initially dominated by Chlorella vulgaris with the co-dominance of Chlorococcum humicolo, Achnanthes minutissima, Cocconeis scutellum and Chroococcus minutus. Patrick (1976) reported that prostrate diatoms, such as Cocconeis and Achnanthes, colonized surfaces during the initial period of biofilm development, followed by the attachment of genera possessing mucilagenous pads or stalks (e.g. Fragilaria and Synedra). Korte \& Blinn (1983) also observed attachment of Achnanthes minutissima and Cocconeis placentula during the early phases of biofilms development, followed by the attachment of horizontally positioned species such as Gomphonema, Nitzschia and Cymbella in stream riffle zones. Miller et al. (1987), while studying diatom succession on sand grains, found increased attachment of low profile diatoms when compared to stalked diatoms. In the present study also, attachment of green algae and low profile diatoms was observed more during the early stages, whereas long-stalked diatoms, filamentous green algae and cyanobacteria colonized more during later stages. It has been reported that closely adhering nature and ability to produce mucilage are attributes that facilitate easy attachment of these organisms during the early stages of colonization (Siver, 1977; Hudon \& Bourget, 1981; Korte \& Blinn, 1983). It has been reported that certain species of Cocconeis are highly competitive as epiphytes in the presence of organic exudates (Tuchman \& Blinn, 1979; Siver, 1980).

In the present study, stalked diatoms such as Gomphoneis olivaceum, Cymbella tumida, Gomphonema sp. and the rosette forming diatoms such as Nitzschia amphibia and N. palea were found in increased 

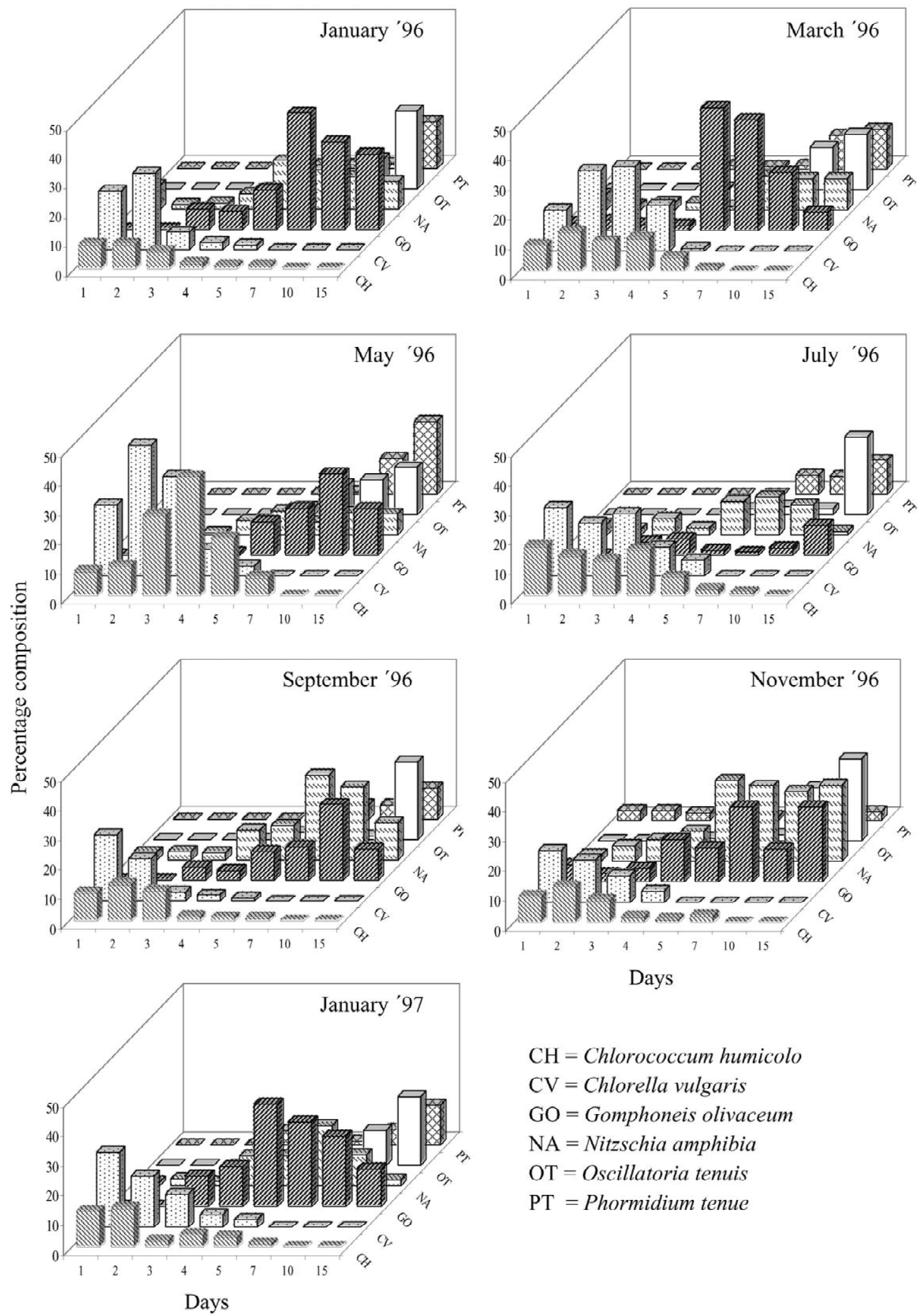

$$
\begin{aligned}
& \mathrm{CH}=\text { Chlorococcum humicolo } \\
& \mathrm{CV}=\text { Chlorella } \text { vulgaris } \\
& \mathrm{GO}=\text { Gomphoneis olivaceum } \\
& \mathrm{NA}=\text { Nitzschia amphibia } \\
& \mathrm{OT}=\text { Oscillatoria tenuis } \\
& \mathrm{PT}=\text { Phormidium tenue }
\end{aligned}
$$

Figure 2. Percentage composition of major biofilms species during the study period. 

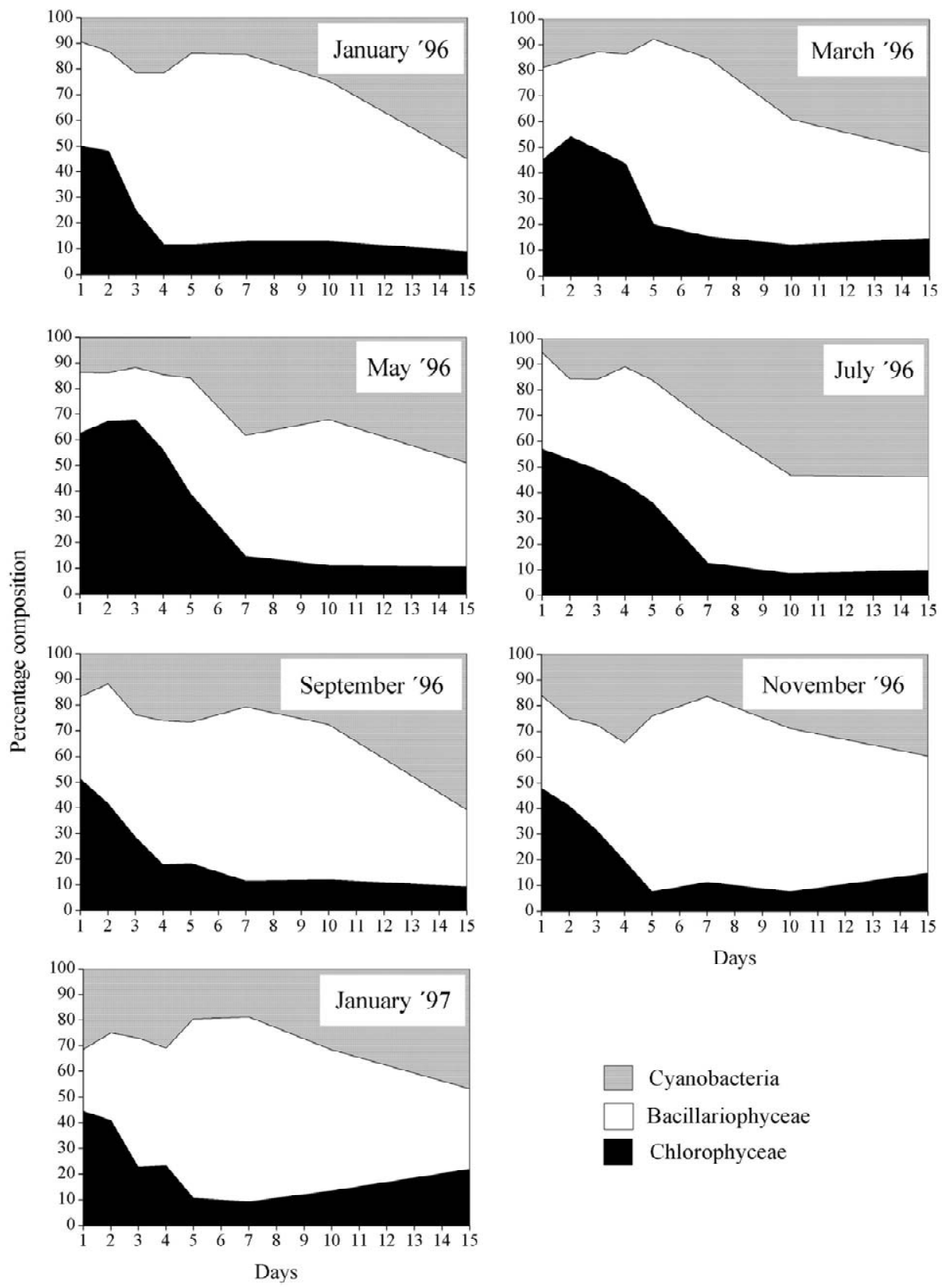

Figure 3. Succession pattern in the biofilms during different months.

numbers after the initial stages (5+ days) of biofilm development. Hoagland et al. (1982) reported that rosette forming diatoms such as Nitzschia, Fragilaria and Synedra colonized the substratum during the later successional stages, along with long-stalked diatoms such as Gomphonema. Korte \& Blinn (1983) also observed greater attachment of Gomphonema, Nitzschia and Cymbella during later stages of biofilm development.
In contrast, Oemke \& Burton (1986) and Stevenson \& Peterson (1989) found that initial (up to 4 days) colonizers were Cymbella minuta and Amphora sp. in both riffle and pool zones, followed by the high abundance of Fragilaria vaucheriae and Synedra ulna in riffles. Cocconeis sp. was dominant in both the habitats due to their rapid doubling rate whereas F. vaucheriae, Synedra ulna and Cymbella minuta 

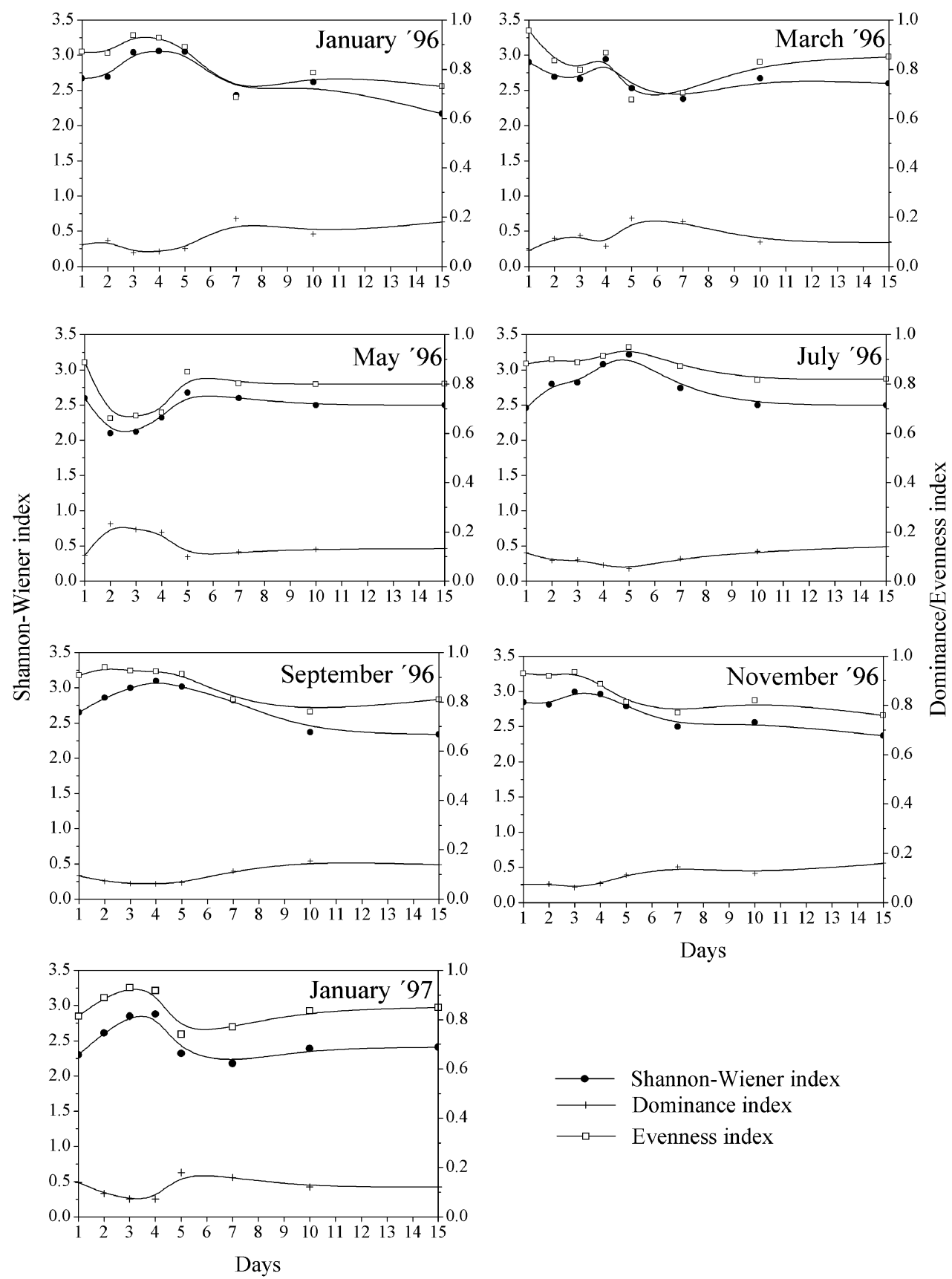

Figure 4. Bimonthly variations in Shannon-Wiener, Dominance and Evenness indices during the study period.

dramatically declined with increasing exposure time. Stevenson \& Peterson (1989) stated that species which dispersed effectively were the initial colonizers while species which reproduced rapidly were the dominant forms in the later succession stages. Acs \& Kiss (1993) reported that the pioneer colonists were mostly ar- aphid diatoms of relatively large size. The large bodied species have an advantage during immigration, because they can settle more rapidly on the substratum; and as a result araphid diatoms are usually more active immigrants than mono and biraphid ones (Stevenson $\&$ Peterson, 1989). The intermediate stage colonizers 
are usually biraphid and monoraphid diatoms with relatively small sizes. Small species are fast reproducers and are better competitors in nutrient rich environments than larger species and the later colonizers are slow immigrants, but good competitors for available nutrients (Sommer, 1981).

The initial colonizers observed in the present study may be fast immigrants and also fast reproducers, as compared to the later colonizers. The colonial green algae such as Pediastrum boryanum, Coleochaete scutata and cyanobacteria such as Gloeocapsa nigrescens were found colonizing after 5 days due to their slow immigirant nature and growth in biofilm. The filamentous green algae such as Klebshormidium subtile, Stigeoclonium tenue and Ulothrix zonata and cyanobacteria such as Calothrix elenkinii, Oscillatoria tenuis and Phormidium tenue were found to attach after 5-7 days of immersion. Most of the filamentous green algae attach themselves using a holdfast whilst the cyanobacteria attach to the substrata by production of mucilage (Scott et al., 1996) and their growth rate is very slow as compared to the green algae and diatoms. The abundance of cyanobacterial filaments in the later stages could be related to their slow growth in the biofilm. Korte \& Blinn (1983) also noted the dominance of cyanobacteria in the later stages of biofilm development. The reduction of early colonizers during the later stages is possibly due to the increased abundance of stalked diatoms and filamentous species, which restrict light penetration (to underlying species) or hinder nutrient transport by interrupting passage of water current to the underlying cells (Oemke \& Burton, 1986).

Stevenson (1986) grouped periphyton community based on their immigration and growth rate: the pioneers have a high initial abundance but decrease with time, the relative abundance of the late colonizers' increases with time, and the intermediates have a relatively more stable abundance than the other groups. In the present study, these three basic types of organisms could be seen during the three different phases of biofilm development. Chlorococcum humicolo, Chlorella vulgaris, Achnanthes minutissima, Cocconeis scutellum and Chroococcus minutus were the pioneer colonizers and the duration of their abundance varied for each species. Filamentous green algae such as Klebshormidium subtile, Stigeoclonium tenue, Ulothrix zonata and the cyanobacterial filamentous forms such as Calothrix elenkinii, Oscillatoria tenuis and Phormidium tenue were the later colonizers. Colonial forms such as Pediastrum boryanum, Coleocheate scutata and Gloeocapsa nigrescens and diatoms such as Amphora coffeaeformis, Gomphoneis olivaceum, Nitzschia amphibia, Nitzschia palea were intermediate colonizers, showing a more stable abundance.

Based on the percentage occurrence, a distinct three phase succession could be observed. The first phase was dominated by Chlorophyceae, the second phase by Bacillariophyceae and the third by cyanobacteria. This study showed that, in the low energy lentic freshwater environment in which it was carried out, biofilms development progressed in such a way that it was initially dominated by unicellular and small colonial green algae, cyanobacteria and horizontally positioned diatoms. It was followed by large colonial green algae and cyanobacteria and vertically positioned rosette and long stalked diatoms. The late phase community was mainly composed of filamentous green algae and cyanobacteria. Earlier work (Rao et al., 1997) in the same fresh water environment has shown that chemical conditions within the biofilm matrix, especially those relating to the nutrient dynamics, undergo changes depending on the age of the biofilms. Using light and dark experiments Rao et al. (1997) conclusively showed that photosynthesising components in the biofilms (microalgae and cyanobacteria) profoundly influence nutrient chemistry within the biofilms. It would be quite interesting to see how changes in species composition, brought about by successional changes, would influence the nutrient conditions within the biofilms matrix and how this, in turn, would further influence the biofilms progression.

\section{Acknowledgements}

We wish to express our sincere thanks to Prof. D. Lalithakumari, Director, Centre of Advanced Study in Botany, University of Madras, Chennai and Dr S.V. Narasimhan, Head, Water and Steam Chemistry Laboratory, BARC Facilities, Kalpakkam for providing laboratory facilities. This work was done under a project sanctioned to one of us (VNRR) by the Board of Research in Nuclear Sciences, Department of Atomic Energy, Government of India. One of the authors (RS) thank the Council of Scientific and Industrial Research (CSIR), Government of India for providing him with travel assistance to present this work at the Second Asian Pacific Phycological Forum held at the Chinese University of Hong Kong, Shatin, NT, Hong Kong. 


\section{References}

Acs, E. \& K. T. Kiss, 1993. Colonization process of diatoms on artificial substrates in the river Dunube near Budapest (Hungary). Hydrobiologia 269/270: 307-315.

APHA, 1989. Standard Methods for Estimation of Water and Waste Water. American Public Health Association, 17th edn., Washington D.C.

Bakke, R. \& P. Q. Olsson, 1986. Biofilm thickness measurements by light microscopy. J. Microbiol. Methods. 5: 1-6.

Brown, H. D., 1976. A comparison of the attached algal communities of a natural and artificial substrates. J. Phycol. 12: 301-306

Callow, M. E., 1986. A world wide survey of slime formation on antifouling paints. In Evans, L. V. \& K. D. Hoagland (eds), Algal Biofouling. Elsevier Science Publishers B.V., Amsterdam: 1-20.

Callow, M. E., 1993. A review of fouling in freshwaters. Biofouling 7: 313-327.

Christensen, B. E. \& W. G. Characklis, 1990. Physical and chemical properties of biofilms. In Characklis, W. G. \& K. C. Marshall (eds), Biofilms. John Wiley \& Sons, New York: 93-130.

Cooksey, K. E. \& W. B. Cooksey, 1995. Adhesion of bacteria and diatoms to surfaces in the sea: A review. Aquat. Microbial Ecol. 9: 87-96.

Desikachary, T. V., 1959. Cyanophyta. New Delhi: Indian Council of Agricultural Research, New Delhi.

Ford, T. E., M. Walch, R. Mitchell, M. J. Kaufman, J. R.Vestal, S. A.Dither \& M. A. Lock, 1989. Microbial film formation on metals in an enriched arctic river. Biofouling 1: 301-310.

Hoagland, K. D., S. C. Roemer \& J. R. Rosowski, 1982. Colonisation and community structure of two periphyton assemblages, with emphasis on the Diatoms (Bacillariophyceae). Am. J. Bot. 69: 188-213.

Hudon, C. \& E. Bourget, 1981. Initial colonization of artificial substrate: commuity development and structure studied by scanning electron microscopy. Can. J. Fish. aquat. Sci. 59: 1371-1384.

Hudson, S. T. \& C. Burke. 1994. Microfouling of salmon cage netting: a priliminary investigation. Biofouling 8: 93-105.

Hustedt, F., 1930. Bacillariophyta (Diatomeae). In Pascher, A. (ed.), Die Susswasser-Flora Mittleuropas. Gustav, Fischer, Jena.

Jeffrey, S. W. \& G. F. Humphrey, 1975. New spectrophotometric equations for determining chlorophyll $a, b$ and $c$ in higher plants, algae and natural phytoplankton. Biochem. Physiol. Pflanzen.167: 191-194.

Johnson, R. E., N. C. Tuchman \& C. G. Peterson, 1997. Changes in the vertical microdistribution of diatoms within a developing periphyton mat. J. N. Am. Benthol. Soc. 16: 503-519.

Korte, V. L. \& D. W. Blinn, 1983. Diatom colonization on artificial substrata in pool and riffle zones studied by light and scanning electron microscopy. J. Phycol. 19: 332-341.

Lowe, R. L., J. B. Guckert, S. E. Belanger, D. H. Davidson \& D. W. Johnson, 1996. An evaluation of periphyton community structure and function on tile and cobble substrata in experimental stream mesocosms. Hydrobiologia 328: 135-146.

Margalef, R., 1958. Information theory in Ecology. Gen. Syst. 3: 36-71.
Miller, A. R., R. L. Lowe \& J. T. Rotenberry. 1987. Succession of diatom communities on sand grains. J. Ecol. 75: 693-709.

Odum, E. P., 1971. Fundamentals of Ecology. W.B. Saunders Company, London.

Oemke, M. P. \& T. M. Burton, 1986. Diatom colonization dynamics in a lotic system. Hydrobiologia 139: 153-166.

Patrick, R., 1976. The formation and maintenance of benthic diatom communities. Proc. am. phil. Soc. 120: 474-484.

Pederson, K., 1990. Biofilm development on stainless steel and PVC surfaces in drinking water. Wat. Res. 24: 239-246.

Philipose, M. T., 1967. Chlorococcales, ICAR, New Delhi.

Pielou, E. C., 1966. The measurement of diversity in different types of biological collections. J. theor. Biol. 13: 131-144.

Prescott, G. W., 1978. How to Know the Freshwater Algae. Wm. C. Brown Company Publishers, Dubuque, Iowa, U.S.A

Rao, T. S., P. G. Rani, V. P. Venugopalan \& K.V. K. Nair, 1997. Biofilm formation in photic and aphotic environments in fresh water system. Biofouling 11: 265-282.

Roemer, S. C., K. D. Hoagland \& J. R. Rosowski, 1984. Development of a freshwater periphyton community as influenced by diatom mucilages. Can. J. Bot. 62: 1799-1813.

Scott, C., R. L. Fletcher \& G. B. Bremer, 1996. Observations on the mechanisms of attachment of some marine fouling cyanobacteria. Biofouling 10: 161-173.

Sekar, R., K. Nandakumar, V. P. Venugopalan, K. V. K. Nair \& V. N. R. Rao, 1998. Spatial variation in microalgal colonization on hard surfaces in a lentic freshwater environment. Biofouling 13: 177-195.

Siver, P. A., 1977. Comparison of attached diatom communities on natural and artificial substrates. J. Phycol. 13: 402-406.

Siver, P. A., 1980. Microattachment patterns of diatoms on leaves of Potamogeton robbinsii Oake. Trans. am. microsc. Soc. 99: 217220.

Sokal, R. R. \& J. Rohlf, 1987. Introduction to Biostatistics, 2nd edition. W.H. Freeman \& Company, New York.

Sommer, U., 1981. The role of $r$ - and $K$-selection in the succession of phytoplankton in Lake Constance. Acta. Oecol. Gener. 2: 327342.

Steinman, A. D. \& C. D. McIntire, 1986. Effects of current velocity and light energy on the structure of periphyton assemblages in laboratory streams. J. Phycol. 22: 352-361.

Stevenson, R. J., 1986. Importance of variation in algal immigration and growth rates estimated by modelling benthic algal colonisation. In Evans, L. V. \& K. D. Hoagland (eds), Algal Biofouling. Elsevier Science Publisher, Amsterdam: 193-210.

Stevenson, R. J. \& C. G. Peterson, 1989. Variation in benthic diatom (Bacillariophyceae) immigration with habitat characteristics and cell morphology. J. Phycol. 25: 120-129.

Tuchman, M. L. \& D. W. Blinn, 1979. Comparison of attached algal communities on natural and artificial substrata along a thermal gradient. Br. phycol. J. 14: 243-254.

Udayakumar, M., S. Chongdar \& R. B. Srivastava, 1998. Microfouling on austentic stainless steel weldments immersed in Bombay harbour waters. Indian J. mar. Sci. 27: 230-232. 